\title{
THE EVOLUTION OF PUBLIC POLICY \\ AND JUDICIAL FUNCTION IN ENGLISH LAW
}

\author{
STAVROS BREKOULAKIS*
}

\begin{abstract}
This article is concerned with the function of English judges in employing the doctrine of public policy to decide cases under common law. For the first time, the article offers a critical appraisal of the recent evolution of public policy and decision making under English law from a structured doctrine of legal rules and limited judicial discretion to an open-ended principle of subjective evaluations. The main thesis of the article is that the latest judicial amendment of the nature of the public policy inquiry constitutes a radical and unnecessary departure from generally accepted propositions on the appropriate function of English judges in addressing issues of public policy.
\end{abstract}

\section{Introduction}

This article is concerned with the function of English judges in employing the doctrine of public policy to decide cases under common law. It is now widely accepted that judicial function and decision making operates within a framework of bounded discretion. ${ }^{1}$ While national legal systems have developed sophisticated bodies of precedent to guide judicial function and decision making, ${ }^{2}$ a number of empirical studies have shown that the way judges evaluate facts and construe legal rules is influenced, at times considerably, by a wide range of extra-legal factors, including surrounding social, economic and political circumstances as well as personal values. ${ }^{3}$ When judges have a choice of various possible legal outcomes, which are all consonant with the law, they tend to choose the legal outcome which is more

\footnotetext{
*Stavros Brekoulakis is a Professor in International Arbitration, Centre for Commercial Law Studies, Queen Mary University of London and an associated member of 3 Verulam Buildings. ${ }^{1}$ Ronald Dworkin, "Hard Cases" (1974) 88 Harv L Rev 1057; Brian Tamanaha, Beyond the Formalistic-Realist Divide (Princeton 2010).

2 Harry T Edwards and Michael A Livermore, "Pitfalls of Empirical Studies that Attempt to Understand the Factors Affecting Appellate Decisionmaking" (2009) 58 Duke LJ 1895.

${ }^{3}$ See the classic study of John Griffith, The Politics of the Judiciary (5 $5^{\text {th }}$ ed, Fontana 1996), and more recently Rachel Cahill-O'Callaghan, "The Influence of Personal Values on Legal Judgments" (2013) 40(4) Journal of Law and Society 596; and in the US, the classic attitudinal studies of Jeffrey Segal and Harold J Spaeth, The Supreme Court and the Attitudinal Model (CUP 1993) and The Supreme Court and The Attitudinal Model Revisited (CUP 2002).
} 
compatible with their personal views or the views of society, as they understand them. ${ }^{4}$

However, while judicial discretion in evaluating facts and interpreting the law is generally accepted, the question of whether judicial creativity can entail judges modifying existing legal rules or introducing new legal rules is more complex and indeed contested not least because it tends to blur the demarcation line between judiciary and legislature. ${ }^{5}$

The debate about the appropriate limits of judicial function is most interestingly connected with the debate surrounding the concept of public policy. Is public policy a general principle of an open-ended nature or a set of legal rules identified with the policy of the law? Judicial function will differ considerably under these two diverse jurisprudential accounts of public policy. If public policy operates as an open-ended general principle, judges will have discretion to introduce new heads of public policy, which would allow them to decide questions on political expediency. By contrast, if public policy functions as a set of legal rules, judges will only be allowed to ascertain the content of existing public policies as these are enshrined in statutes and the common law.

Despite its theoretical and practical significance, the debate about public policy and judicial function appears to have escaped the focus of modern legal discourse both in England and internationally. Relatively few studies on this topic exist, and these mostly date back to the beginning or the middle of the twentieth century. ${ }^{6}$ By contrast, contemporary scholarship tends to focus on the content of public policy rules in certain fields of law, mainly international arbitration and private international law. ${ }^{7}$

Yet, as the recent decision of the UK Supreme Court (SC) in Patel v Mirza [2016] shows, 8 the question of whether judges can employ public policy to introduce

\footnotetext{
${ }^{4}$ John Bell, Policy Arguments in Judicial Decisions (OUP 1983) 227.

${ }^{5}$ Dennis Lloyd, "Reason and Logic in the Common Law" (1948) 64 LQR 468.

${ }^{6}$ Mainly, WSM Knight, "Public Policy in English Law" (1922) 38 LQR 207; Percy Winfield, "Public Policy in the English Common Law" (1928-29) 42 Harv L Rev 77; Dennis Lloyd, Public Policy: A Comparative Study in English and French Law (The Athlone Press 1953) and John Shand, "Unblinkering the Unruly Horse: Public Policy in the Law of Contract" (1972) 30(1) CLJ 144. See also Bell (n 5) who, while he examines judicial function in public policy, takes a broader approach examining policies in judicial reasoning.

7 See for example, Pierre Lalive, "Transnational (or Truly International) Public Policy and International Arbitration" in Pieter Sanders (ed), Comparative Arbitration Practice and Public Policy in Arbitration, ICCA Congress Series No 3 (1987) 301; Alex Mills, "The Dimensions of Public Policy in Private International Law" (2008) 4 J Priv Int'1 L 213. See also discussion on public policy in the illegality defence: Nicholas Strauss, "Ex Turpi Causa Oritur Actio?" (2016) 132 LQR 236.

8 Patel v Mirza [2016] UKSC 42; [2017] AC 467.
} 
new rules on the basis of the interests of the public at large is as important as ever. As is explained in detail below, the majority SC ruling in Mirza substituted the public policy rule on illegality (ex turpi causa), which stretched back to the eighteenth century authority of Holman $v$ Johnson, ${ }^{9}$ with a broader inquiry as to whether enforcement of a claim would be harmful to the public interest. As the majority in Mirza held, this broader inquiry should be decided on the basis of a range of factors and policies competing with the public policy prohibiting illegality.

Until now, existing commentary on Mirza has focused on the impact of the decision on the illegality rule, leaving unexplored the broader and important questions on public policy and judicial function. ${ }^{10}$ For the first time, the article offers a critical appraisal of the recent evolution of public policy under English law from a structured doctrine of legal rules and limited judicial discretion to an open-ended principle of subjective evaluations. The main thesis of the article is that the latest judicial amendment of the nature of the public policy inquiry constitutes a radical and unnecessary departure from generally accepted propositions on the appropriate function of English judges in addressing issues of public policy.

The article is divided into two parts. The first part takes a historical and doctrinal approach looking into how the doctrine of public policy has developed since its inception and in particular in the last two centuries. As the analysis shows, since the beginning of the twentieth century in particular, the concept of public policy in English law evolved away from the generalisations of the earlier years into a structured doctrine of legal rules which accorded English judges limited discretion to ascertain what is good for the public at large. Under this modern version of the public policy doctrine, English judges could refuse enforcement of a claim as being against public policy only if the claim violated policies which were crystallised into statutory or common law. An English judge had no discretion to introduce a new rule of public policy on the basis of what the judge believed would benefit the public interest or on the basis of considerations of justice. While the modern doctrine of public policy was accused of being too rigid occasionally leading to harsh results, it seemed consistent with the general approach of English law which generally allows little room for value judgements.

\footnotetext{
${ }^{9}$ Holman v Johnson [1775] 1 Cowp 341, 343.

${ }^{10}$ e.g., Sarah Green \& Alan Bogg (eds), Illegality After Patel v Mirza (Hart 2018); James

Goudkamp, "The End of an Era? Illegality in Private Law in the Supreme Court" (2017) 133

LQR 14.
} 
The second part discusses the radical evolution of the doctrine of public policy in the wake of the UK Supreme Court decision in Mirza. As is suggested, the range-of-factors approach currently favoured by English law invites English judges to engage in open-ended and highly subjective evaluations without the benefit of a guiding public policy test or standard. This approach to decision making, which is akin to unfettered discretion, allows English judges to introduce new rules on public policy on the basis of what they believe would benefit the public interest or on the basis of considerations of justice, and as such, runs contrary to the way they have traditionally been exercising their judicial function.

Examining judicial function within the limits of the public policy doctrine in England is an important dispute resolution question which matters not only for English law but also for the field of international arbitration. English law is the most popular choice of law in international contracts, ${ }^{11}$ and the English doctrine of public policy has been the subject of a number of important decisions in international arbitration, including in investment arbitration. ${ }^{12}$ The question of what is the appropriate scope and nature of judicial function under English law and public policy can have significant implications on the appropriate limits of arbitrators' decision making in issuing international arbitral awards.

\section{Historical development of the concept of public policy in English law}

The inquiry into public policy brings us directly into the centre of a broader debate implicating judicial function and decision making. ${ }^{13}$ In this connection, two conflicting accounts of public policy have been offered.

One school of thought posits that English judges cannot introduce new heads of public policy because judicial function is constrained by strict rules of legal precedent. ${ }^{14}$ While judicial function tends to be influenced by evolving social and economic circumstances when judges are called to identify the content of public policy rules, the rules of public policy effectively remain the same, unless the legislator intervenes. On this view, English judges are bound by

\footnotetext{
${ }^{11}$ E.g. 40 per cent of respondents to the the 2012 International Arbitration Survey (Queen Mary University of London and White \& Case) have stated that English law was their most frequent choice for "neutral" law (http://www.arbitration.qmul.ac.uk/media/arbitration/docs/2012_International_Arbitratio n_Survey.pdf) [Accessed 28 October 2018].

12 E.g. World Duty Free Co. Ltd. v. Republic of Kenya, ICSID Case No. ARB/00/7 and Metal-Tech Ltd. v. Republic of Uzbekistan, ICSID Case No. ARB/10/3.

${ }^{13}$ See Shand (n 6) 144.

${ }^{14}$ Judicial authority for this view extends back to Egerton $v$ Brownlow [1853] 4 HLC 1, 122-4 (Parke) and Janson v Driefontein Consolidated Mines Ltd [1902] AC 484.
} 
previous rulings on public policy in the same way that they are bound by legal precedent in other fields of the common law.

Another school of thought supports the view that public policy cannot be viewed as a set of fixed rules. Judges, it is argued, should enjoy discretion in determining what is good for the public welfare and, if necessary, should be able to introduce new rules of public policy to address complex legal issues that exist in modern society. ${ }^{15}$ According to this view, judicial discretion in determining the content of public policy is not to be confused with law reform; rather, it is the recognition that legal rules are built upon certain implicit moral and social assumptions which may fundamentally change in the course of time. ${ }^{16}$

To provide a contemporary account of the doctrine of public policy in English law and illustrate the way English judges function in deciding questions involving public policy it is instructive to first look into the historical development of the doctrine, whose conceptual origins may be traced back many centuries.

\section{i. Early modern period}

Public policy's antecedents can be found as early as in the fifteenth and sixteenth centuries ${ }^{17}$ when English courts refused to enforce certain conditions on the basis that they were "encounter common ley" ("against the common law"), ${ }^{18}$ or "encounter le necessity del commonwealth" ("against the needs of the commonwealth") ${ }^{19}$ or "encounter de ley de Dieu" ("against the law of God"). ${ }^{20}$ Winfield in his seminal study on the subject noted that the concept of public policy was unconsciously or half-consciously pervading, albeit under several different names, the whole English legal system at a time when little statutory or common law existed and the majority of cases would often raise new legal matters for English judges. In those times, when English judges laid down a new rule or moderated existing rules that were harsh, they did it solely for the benefit of the public. ${ }^{21}$ Even in the sixteenth and seventeenth centuries the concept of public policy was concealed under widely abstract terms that

\footnotetext{
${ }^{15}$ Lloyd (n 6) 115-16. This view is also supported by Egerton v Brownlow (n 12) (Pollock CB pp 149-51); Rodriguez $v$ Speyer Bros [1919] AC 59, 88-91 (Lord Haldane); Wilson v Carnley [1908] 1 KB 738, Fender $v$ Mildmay [1938] AC 11-12 (Lord Atkin), Naylor $v$ KIG [1918] 1 KB 331, 342. cf Bell (n 5) who takes a position in the middle by expanding on the interstitial legislator model. ${ }^{16}$ Lloyd (n 6) 128.

17 See Knight (n 6).

${ }^{18}$ In Dyer's case [1414] 2 Hen V, fol 5, pl 26.

${ }^{19}$ Anon. (1586) Moo. No 379.

${ }^{20}$ Prat v Phanner [1586] Mo. No 683.

${ }^{21}$ Winfield (n 6).
} 
allowed judges to fill gaps in the law on the basis of what was considered to be good for the community. ${ }^{22}$

The concept of public policy started to acquire more precise meaning and technical shape much later. In the eighteenth century, statutory law and case law become denser and tended to cover more ground in English law, which was previously occupied by abstract legal concepts, such as reason, convenience and policy. As a result, public policy ceased to pervade English law as a whole and eventually shrank to certain legal fields, 23 such as agreements in restraint of law, ${ }^{24}$ the rule against perpetuities, ${ }^{25}$ contracts tainted by fraud and marriage contracts. ${ }^{26}$

However, while it lost its all-pervasive nature, public policy in the eighteenth century remained an open-ended concept that was largely considered as a valid basis of judicial legislation. ${ }^{27}$ So wide was the range of discretion accorded to English judges of the time that they had authority to invalidate a contract, which was otherwise not prohibited by law or legal precedent, if they considered the contract to be against principles of morality or policy.

For example, in Jones $v$ Randall (1774), ${ }^{28}$ an action was brought for the recovery of money won upon a wager. Lord Mansfield stated that while a contract such as a wager was prohibited neither by statute nor by precedent, it could be rendered unenforceable if it was against certain principles, such as "principles of morality" or "principles of sound policy". ${ }^{29}$ He noted that common law would be a "strange science" if it was decided upon precedents only; rather, he was of the view that English law depended upon principles which run "through all the cases according as the particular circumstances of each have been found to fall within the one or other of them". ${ }^{30}$

Such an open-ended approach brought public policy very close to political expediency. In The Earl of Chesterfield $v$ Sir Abraham Janssen, ${ }^{31}$ Lord Hardwick LC regarded the concept of "publick utility" as including "political arguments in the fullest sense of the word" which must be given "great weight in the

\footnotetext{
${ }^{22}$ Knight (n 6) 207.

${ }^{23}$ Winfield (n 6) 84.

${ }^{24}$ Michel v Reynolds [1711] I P Wms 181.

${ }^{25}$ Duke of Norfolk's Case [1681] 3 Ch Cas I, 20.

${ }^{26}$ Chesterfield $v$ Janssen [1750] 1 Atk 301.

27 Winfield (n 6) 86.

${ }^{28}$ Jones $v$ Randall [1774] 1 Cowp 37.

29 ibid 39.

30 ibid.

${ }^{31}$ Chesterfield $v$ Janssen (n 26).
} 
consideration" of the court because they concern the good government of a nation. ${ }^{32}$

\section{ii. The nineteenth century}

However, as English statutory and case law further evolved in the nineteenth century, giving clear shape to legal principles and laying down legal rules, the account of public policy as a source of judicial legislation was about to be challenged. This was a period during which judges started, albeit with some exceptions, ${ }^{33}$ to look at public policy in more critical terms, beginning to realise that the wide scope and fluid nature of the doctrine had to be constrained "unless it was to thrust them into a position which Parliament alone could occupy, or to infect with a virus of uncertainty principles which had long been settled by case law". ${ }^{34}$ It is no coincidence that the famous reference to public policy as an "unruly horse" was made at that time in Richardson $v$ Mellish, ${ }^{35}$ where the English court refused to hold an agreement, whereby the plaintiff would resign the command of a ship in favour of the defendant's nephew upon receiving in exchange the command of another ship, as against public policy. Mr Justice Burrough aptly articulated a general feeling of unease among the majority of judges of the time that the doctrine of public policy as a general principle of law had the potential to disturb the delicate balance of powers between the judiciary and "that high tribunal, namely the legislature" which alone has the authority and the means of bringing before it all relevant, legal as well as non-legal, considerations to decide complex questions of policy. ${ }^{36}$

Against this background of judicial disquiet towards public policy, the outcome of the landmark decision of the House of Lords in Egerton $v$ Brownlow, ${ }^{37}$ in the middle of the nineteenth century, came as a surprise. In his will, the Earl of Bridgewater had devised extensive real estate in favour of Lord Alford with the condition that if he died without having acquired the title of Duke or Marquis of Bridgewater, the gift would be void. While the legal issue was whether the condition should be enforced or not, the broader and more important question in Egerton concerned the nature of public policy and the appropriate boundaries of judicial function. The judges were summoned by the

\footnotetext{
32 ibid 352.

${ }^{33}$ See for example, the decision in Gilbert $v$ Sykes [1812] 16 East 150, where the court held in the context of curious factual circumstances that a contract whereby Sykes received a hundred guineas from Gilbert in exchange for paying Gilbert a guinea a day until the death of Napoleon Bonaparte was against public policy because it had a tendency to produce a public mischief, namely the assassination of a public enemy against the law of nations.

34 Winfield (n 6) 86.

${ }^{35}$ Richardson v Mellish [1824] 2 Bing 229, 252 (Justice Burrough).

36 ibid 243 (Best CJ).

${ }^{37}$ Egerton v Brownlow [1853] 4 HLC 1.
} 
House of Lords to give their views. The vast majority of them opined that public policy was the policy of the law only. They noted that an activity or a contract would be illegal as against public policy only when it would be contrary to the principle established by statutory law or precedent, rather than when it would be considered inexpedient by the judges. Baron Parke expressed this view forcefully, observing:

Public policy is a vague and unsatisfactory term, and calculated to lead to uncertainty and error, when applied to the decision of legal rights. It is the province of the statesman, and not the lawyer, to discuss, and of the Legislature to determine, what is best for the public good, and to provide for it by proper enactments. It is the province of the judge to expound the law only ... not to speculate upon what is the best, in his opinion, for the advantage of the community. [W] are not ... authorised to establish as law everything which we may think for the public good, and prohibit everything which we think otherwise. ${ }^{38}$

However, the view of the majority of the judges was dismissed. Instead, the House of Lords endorsed the view of Lord Chief Baron Pollock who offered an account of public policy that amounted to an open-ended principle of law, according judges wide discretion to decide any new case that may arise on the basis of what they might consider to be good for the "public welfare". As he noted, judges may not be in a better position than other members of the community to ascertain what is good for the public, but that would not be a valid reason for a judge to refuse to decide upon such a question on the basis of general principles derived from former decisions. ${ }^{39}$

Accordingly, the majority of the Lords held that the condition stipulated by the Earl of Bridgewater, although lawful, was against public policy because it had the "tendency" to cause Lord Alford to possibly use unlawful and corrupt means to secure the title of the Duke or Marquis of Bridgewater for the Earl.

However, Egerton notwithstanding, judges in the late nineteenth century remained doubtful and increasingly sceptical of a fluid concept of public policy, which was akin to political expedience. ${ }^{40}$ Unlike the Lords in Egerton, English judges appeared to feel uncomfortable with the idea that a "tendency", rather than the terms of the contract itself, could, if found to be harmful to the public in general, render an otherwise valid contract unenforceable. ${ }^{41}$

\footnotetext{
38 ibid 123.

39 ibid 149.

${ }^{40}$ Knight (n 6) 212-13 and Bell (n 4) 157.

${ }^{41}$ Cf Fender v Mildmay (n 13) 12-13.
} 


\section{iii. The twentieth century}

a. Reservation against an open-ended concept of public policy

By the beginning of the twentieth century, the reservation against an openended concept of public policy had become the primary consideration for English judges who confirmed in a number of cases that judicial function required them to interpret existing legal rules and precedent rather than expound on, or invent new heads of, public policy. ${ }^{42}$ Approaching the doctrine of public policy cautiously, English judges were mindful not to invalidate contracts which may be considered in the views of individual judges as generally "repugnant to the interests of the State" or phrases to that effect even in the context of exceptional circumstances such as war. In Janson $v$ Driefontein Consolidated Mines [1902], a South African company insured a large amount of gold with Lloyd's against capture during its transit from South Africa to England. The government of South Africa eventually seized the treasure during the transit and war was later declared between South Africa and Great Britain. At the end of the war the South African company brought a claim against Lloyd's to recover the amount due under the policy. The House of Lords rejected Lloyd's position that the insurance policy was against public policy on the basis that a contract with a foreign company of a State, which subsequently becomes an enemy, is injurious to the public interest and the interests of Britain. As Halsbury LC noted, a statement that declares a contract against public policy is not in and of itself a valid statement in a court of law. ${ }^{43}$ A contract cannot be invalid because, in the views of a judge, it is against public policy, but because it is against a legal rule or a principle of public policy which prohibits certain classes of contracts, for example, contracts in restraint of trade. ${ }^{44}$

Similar considerations guided judicial function in non-commercial disputes implicating circumstances that were (at least at the time) socially sensitive, where one might have thought that public policy would have played a more prominent role. Thus, for example, in Bowman $v$ Secular Society [1917],45 it was held that the registration of a secular society as a company with the main object to promote the belief that human conduct should be based upon natural knowledge rather than supernatural beliefs was not contravening English

\footnotetext{
42 See for example Elliman $v$ Carrington [1901] 2 Ch 279, Wallace, Re, Champion v Wallace [1920] 2 Ch 274, 303 (Younger LJ) and Rodriguez v Speyer Bros [1919] AC 59, 126 (Lord Summer).

43 Janson v Driefontein Consolidated Mines Ltd (n 12) 491. See also Lord Davey at 500 and Lord Lindley at 507.

44 ibid; cf also Lord Reading in Continental Tyre and Rubber Co v Daimler Co [1915] 1 KB 893, 912, 918.

${ }^{45}$ Bowman v Secular Society [1917] AC 427-28.
} 
public policy on the basis that it undermined Christianity, as the plaintiff had suggested. For Lord Buckmaster, an offence against Christianity, to the extent that such offences were recognised by the law of the time, were either statutory or criminal offences at common law. ${ }^{46} \mathrm{He}$ was thus unable to see how an offence against Christianity existed at all on the basis of being against the general notion of public policy, without being the subject of prosecution. ${ }^{47}$

Equally, in Fender $v$ Mildmay [1938], 48 the House of Lords, overturning the decision of the Court of Appeal, held that a promise made by a spouse to marry a third person after his marriage was dissolved was not void as against public policy. Lord Atkins noted that the whole notion that a contract (or in that case a promise) should be rendered void on the basis that it generally presents a danger to the public interest was fanciful and unreal. ${ }^{49}$

\section{b. A more structured doctrine}

Overall, since the beginning of the twentieth century, the concept of public policy in English law has evolved away from the generalisations of the earlier years into a more structured doctrine of exceptional character. ${ }^{50}$ While there have been dissenting opinions expressing the view that judges should be able to take judicial notice of public policy circumstances which lie outside the law, ${ }^{51}$ English courts in the last century have largely taken a restrictive approach to public policy and the scope of judicial function entailed therein. This can be summarised in four propositions: first, public policy is not a general legal principle that pervades English law; rather, it is confined to certain fields of law, where the public policy prohibition is typically expressed in the form of a legal rule. Second, it would be inappropriate for an English judge to render an otherwise valid contract void on the basis that this contract is considered to be injurious to the interests of the public or any similar reasoning to that effect. ${ }^{52}$ A contract can be refused enforcement as being against public policy in exceptional circumstances and only if it violates certain policies of fundamental significance that have, importantly, been crystallised into statutory or common

\footnotetext{
46 ibid 477.

47 ibid.

48 Fender $v$ Mildmay (n 15).

49 ibid 22 (Lord Atkin); cf also Lord Thankerton, at 23, stating that the proper function of the courts in questions of public policy is to expound, and not to expand, such policy.

$50 \mathrm{cf}$ Lord Atkinson in Rodriguez $v$ Speyer (n 15) at 89: "The principles of public policy so adopted have, as numerous authorities conclusively show, crystallised, as it were, into strict and rigid rules of law to be applied, to use Lord Stowell's words, "with rigour'."

${ }^{51}$ Rodriguez $v$ Speyer (n 15) at 79 (Lord Haldane) in the minority: "There are many things of which the judges are bound to take judicial notice which lie outside the law properly so called, and among those things are what is called public policy and the changes which take place in it. The law itself may become modified by this obligation of the judges."

52 As Lord Atkin noted in Fender v Mildmay (n 15) 12.
} 
law rules. Third, it would be inappropriate for an English judge to disregard a legal rule of public policy because the judge disapproves of the policies underlying that rule. Fourth, it would be inappropriate for an English judge to introduce a new rule of public policy on the basis of what the judge believes would be the most appropriate policies to pursue for the benefit of the public. ${ }^{53}$

\section{c. Judicial discretion}

The above propositions should not be taken to suggest that the doctrine of public policy allows no room for discretion. In applying public policy, English judges have always enjoyed a certain degree of discretion in two circumstances in particular.

In the first place, judges enjoy a limited degree of discretion when a dispute gives rise to a novel legal issue. In such a circumstance (nowadays rare), public policy operates as a general legal principle rather than a fixed rule. In this type of "hard case", where neither statute nor precedent offers a crystallised rule of public policy, judges can address a novel legal question, by bringing moral, social and political perspectives into legal reasoning. ${ }^{54}$

However, even in addressing novel situations, judicial discretion is not unfettered. ${ }^{55}$ The decision on the novel question must be consistent with existing rules and principles of public policy. ${ }^{56}$ Even deciding hard cases on public policy, judges are not free to create a new rule of law, or come up with novel legal policies, or substitute their preferred policies for the existing policies of the law. Considerations of coherence and consistency play an important role in constraining judicial creativity. ${ }^{57}$

Bell has argued that, in novel situations, public policy can be used as a justification for introducing new rules of law, and cites the example of Gray $v$ Barr 58 to that effect. In Gray, Mr Barr armed with a loaded shotgun went to $\mathrm{Mr}$ Gray's house looking for his wife, who had been having an affair with Mr Gray. Mr Barr's gun went off in a struggle and killed Mr Gray, whose father and widow subsequently claimed damages against Mr Barr for unlawfully causing Mr Gray's death. Mr Barr claimed an indemnity from insurers under a "hearth and home" policy, which provided for indemnification against damages which

\footnotetext{
${ }^{53}$ Rodriguez v Speyer (n 15) 59.

54 See typically Benjamin Cardozo, The Nature of the Judicial Process (Yale UP 1921) and American Realists such as Karl Llewellyn, The Common Law Tradition: Deciding Appeals (Little Brown and Co 1960).

55 Even Realists admit constraints in judges' discretion in hard cases. See Llewellyn ibid 53.

${ }_{56}$ Neil MacCormick, Legal Reasoning and Legal Theory (Clarendon 1978) ch 5.

57 Bell (n 4) 228.

${ }^{58}$ Gray v Barr [1971] 2 QB 554 (CA).
} 
Mr Barr would be liable to pay in respect of bodily injury to a third person. While there was neither any contractual provision in the policy nor any settled public policy rule that would prevent an insured from claiming from his insurance policy in those circumstances, the Court of Appeal held that $\mathrm{Mr}$ Barr's claim was barred by public policy. However, the Court of Appeal did not introduce a new rule on the basis of a new policy; it simply extended existing rules and confirmed policies existing in the field of motor manslaughter to address the novel situation where a man who accidentally killed his wife's lover attempts to recover from his insurance policy. As Lord Denning MR held, in the case of a motor manslaughter the insured is entitled to recover damages caused by his conduct unless his conduct is wilful and culpable. ${ }^{59}$ Employing the concept of public policy, he then applied this legal rule to find that Mr Barr was not allowed to recover indemnity for the bodily injury which Mr Barr wilfully and culpably caused. ${ }^{60}$ To arrive at this conclusion Lord Denning did not introduce a new policy or a new rule. He meticulously identified existing common law rules and principles citing previous cases in the area of motor manslaughter. ${ }^{61}$

In the second place, judges enjoy a degree of discretion when they are called to decide on competing public interests in certain areas of social and economic activity. In these circumstances, the common law has developed public policy rules whose application is predicated upon flexible tests which allow judges to take account of broader considerations in deciding whether a contract is against public policy.

This is, for example, the case in the field of restraint of trade. Restraint of trade agreements require judges to resolve the tension between the right of a professional association and an employer to lay down rules for its members and employees on the one hand, and the interests of the public, including those of the individual members and employees, that all persons exercise their trade freely on the other hand. To resolve the tension, common law rules have developed a public policy rule, exemplified in Nordenfelt $v$ Maxim Nordenfelt Guns and Ammunition, 62 that an agreement that purports to restrain trade and interfere with individual liberty of action is void unless "it is reasonable in reference to the interest of the parties concerned and reasonable in reference to the interests of the public, so framed and so guarded as to afford adequate

\footnotetext{
59 ibid 568-69.

60 ibid 569.

${ }^{61}$ In the Estate of Hall [1914] P 1, and Hardy v Motor Insurers' Bureau [1964] 2 QB 745.

62 Nordenfelt $v$ Maxim Nordenfelt Guns and Ammunition [1894] AC 535, 565.
} 
protection to the party in whose favour it is imposed, while at the same time it is in no way injurious to the public".63

\section{d. A balancing exercise}

Such a widely formulated test on the basis of reasonableness requires English courts to perform a balancing exercise, which entails engagement with broader considerations concerning the interests of the public and the appropriate boundaries on individual liberty of action. While such a balancing exercise necessarily involves the court in value judgements in the light of the public interest, ${ }^{64}$ the decision on whether a restraint of trade is against public policy will be taken on the basis of existing policies of the law as these are captured by statutory law and common law principles. Specifically, the fact that individual rights and liberty of action, including freedom of contract, are presently recognised as important organisational principles of our society and as the primary means of achieving collective prosperity must be taken as the basis of a judge's decision in balancing between the competing interests in a restraint of trade situation. ${ }^{65}$ It would be inappropriate for the courts to engage in a broad debate about competing theories of political economy and about whether liberty of trade is a worthy protected policy. ${ }^{66}$ While the courts have on a number of occasions acknowledged, mainly as a fait accompli, economic and social changes that have occurred in our society, 67 they are not the appropriate forum for resolving debates on social or economic policy. ${ }^{68} \mathrm{As}$ Ungoed-Thomas J noted in Texaco Ltd v Mulberry Filling Station Ltd ${ }^{69}$ :

[T] he question which such reasonableness raises would thus not be whether the restraint might be less in a different organisation of industry or society, or whether the abolition of the restraint might lead to a different organisation of industry or society and thus, on balance of many considerations, to the economic or social advantage of the country, but whether the restraint is, in our industry and society as at present organised and with reference to which our law operates, unreasonable in the public interest as recognised and formulated in such principle or proposition of law. ${ }^{70}$

\footnotetext{
${ }^{63} \mathrm{ibid}$ (Lord Macnaghten).

${ }^{64}$ Bell (n 4) 183.

65 ibid.

${ }^{66}$ cf Lord Finlay in Crown Milling Co $v$ R [1927] AC 394, stating that it is not part of the court's function to express views on economic theories.

${ }^{67}$ Such as the recognition of the unequal bargaining position of an employee vis-à-vis his employer as accepted in Mason v Provident Supply Co [1913] AC 724. See Lloyd (n 6) 138.

68 ibid.

${ }^{69}$ Texaco Ltd v Mulberry Filling Station Ltd [1972] 1 WLR 814.

70 ibid 828.
} 
While originally Ungoed-Thomas's approach was the subject of criticism on the basis that it subsumes interests of the public into the interests of the parties, ${ }^{71}$ it is now acknowledged that his views are supported by sound arguments of policy in that courts are not the appropriate forum for assessing economic evidence and balancing the interests of conflicting groups in a society. ${ }^{72}$

In conclusion, over the course of the last century in particular, clear doctrinal limitations have been placed upon the concept of public policy and associated judicial function. As a result, the modern concept of the doctrine comprises mostly rules and some limited value judgements. ${ }^{73}$ Judges have generally limited discretion when applying the rules of public policy, except in the two circumstances discussed above, namely when they address a novel situation and when applying rules that are predicated on a flexible test which allows them to mediate considerations of public policy through more open questions such as what is reasonable or not. ${ }^{74}$ While the overall rigidity of the doctrine leaves scope for harsh results, ${ }^{75}$ which often make the courts reluctant to apply it,76 it has always seemed consistent with the general approach of English law which has largely opposed discretion, particularly in the area of contract law. ${ }^{77}$ The limited scope of the doctrine appears also consonant with the general aversion of common lawyers to the use of inherently subjective notions, such as the notion of public morality or the interests of justice and the generally recognised predilection of the common law for objective standards, ${ }^{78}$ especially for the purposes of invalidating otherwise valid agreements.

By contrast, continental civil laws typically enshrine the concept of morality in statutory provisions, which allows civil law judges to invalidate contracts if they contravene good morals. Importantly, because the provisions of the civil codes relating to good morals contain no exposition of the meaning of the term and because civil law systems generally lack a doctrine of binding precedent, civil law judges enjoy wide discretion in expounding rules of morality. ${ }^{79}$

\footnotetext{
${ }^{71}$ John D Heydon, "Recent Developments in Restraint of Trade" (1975) 21 McGill LJ 325.

72 Hugh Beale, Chitty on Contracts (32nd ed, Wildy 2015) 16-106.

73 Jonathan Mance, "Ex turpi causa - when Latin avoids liability" (2014) Edin LR 176.

$74 \mathrm{ibid}$.

${ }^{75}$ See Shand (n 6) 165.

${ }^{76} \mathrm{cf}$ Lord Sumption in Apotex admitting that "The main reason for the disordered state of the case law is the distaste of the courts for the consequences of applying their own rules, consequences which Lord Mansfield CJ had pointed out two centuries ago" in Les Laboratoires Servier v Apotex [2012] EWCA Civ 593; [2013] Bus. L.R. 80.

77 Mance (n 73) 192.

${ }^{78}$ Lloyd (n 6) 150.

${ }^{79}$ Lloyd (n 6) 5; morals are enshrined, for example in art 6 of the French Civil Code, which provides that "statutes relating to public policy and morals may not be derogated from by private agreements" and art 1133, "A cause is unlawful where it is prohibited by legislation, where it is contrary to public morals or to public policy."
} 
Indeed, French courts are permitted to render void any agreement which they consider is against morality or public order even if this agreement is not contrary to the law. ${ }^{80}$ As Lloyd has noted, the fundamental difference in the judicial function under public policy allows a civil law judge "to decide the issue before him, if not more light-heartedly, at least in a rather more experimental frame of mind than that of a common law judge" ${ }^{\prime 81}$

While moral considerations have often been used by common law as a justification for the development of a public policy rule, for example the rule against illegality, morality or justice, they are neither enshrined in the public policy rule itself nor used as a general test for the application of a public policy rule.

e. The importance of the English doctrine of public policy on international arbitration

Examining the public policy doctrine in England matters not only for English law but also for the field of international arbitration, with the appropriate scope of judicial function under English public policy being the subject of a number important international arbitral awards. For example, in the World Duty Free Co. Ltd. $v$. Republic of Kenya decided by an investment treaty tribunal under the rules of the International Centre for Settlement of Investment Disputes (ICDIS), the investor, World Duty Free, initiated ICSID arbitration against the Republic of Kenya for breach of the contract in 2004. Kenya argued that that the contract, which was governed by English law, had been procured by the payment of $a$ US $\$ 2 m$ bribe and was, consequently, voidable. The investor claimed that its claim should not be dismissed on the grounds of illegality on the basis that, inter alia, public policy considerations prohibited Kenya to profit from its own illegalities, namely from enjoying benefit of its contractual bargain despite its role in the illegal activity underlying the transaction.

However, the tribunal found that the application of a English public policy rule is not amenable to equitable corrections. While it acknowledged that the claimant had been solicited to offer a bribe by the Kenyan President himself, and that for that reason the claimant was possibly justified to "feel strongly the unfairness of the legal case now advanced by Kenya," 82 the tribunal noted that "as regards public policy ... the law protects not the litigating parties but the public; or in this case, the mass of tax-payers and other citizens making up one of the poorest countries in the world." 83

\footnotetext{
80 Lloyd (n 6) 117.

81 ibid 119.

82 World Duty Free Co. Ltd. v. Republic of Kenya, ICSID Case No. ARB/00/7, para.180.

${ }^{83}$ World Duty Free Co. Ltd. v. Republic of Kenya, ICSID Case No. ARB/00/7, para. 181.
} 
The same approach was taken by another investment treaty tribunal in the Metal-Tech Ltd. v. Republic of Uzbekistan, which dismissed the claimant's claims on the grounds that the contract under which the claims were made was procured by bribery. While the tribunal acknowledged that the outcome in cases of corruption often appear to challenge perceptions of fairness and justice, it pointed out that the main justification of the public policy defence is to promote "the rule of law" rather than "to punish one party at the cost of the other". ${ }^{84}$

However, as the following section will explain, the recent Supreme Court decision in Patel $v$ Mizra not only has changed the nature of the inquiry in relation to the rule on illegality, but appears to radically depart from generally accepted, indeed settled, propositions on the nature of the public policy and associated judicial function under English law.

\section{The latest approach to public policy and judicial function in English Law}

\section{$i$. The rule on illegality}

While Mirza concerns a subset of the public policy doctrine, namely the public policy rule on illegality, the Supreme Court's ruling may potentially have broader ramifications on the doctrine of public policy and associated judicial function. To appreciate the Supreme Court's decision on Mirza, it is necessary to look first into the illegality rule and its development until 2016.

The rule on illegality has been traditionally underpinned by clear public policy justifications originating from the Latin maxim ex turpi causa non oritur actio. 85

Over the years, English courts distilled the originally abstract content of the ex turpi causa principle into a rule, which mainly operated as a procedural defence, preventing a claimant from recovering when the claimant's cause of action (either contractual or in tort) was founded on illegality. ${ }^{86}$

\footnotetext{
${ }^{84}$ See Metal-Tech Ltd. v. Republic of Uzbekistan, ICSID Case No. ARB/10/3, para. 389: "While reaching the conclusion that the claims are barred as a result of corruption, the Tribunal is sensitive to the ongoing debate that findings on corruption often come down heavily on claimants, while possibly exonerating defendants that may have themselves been involved in the corrupt acts. It is true that the outcome in cases of corruption often appears unsatisfactory because, at first sight at least, it seems to give an unfair advantage to the defendant party. The idea, however, is not to punish one party at the cost of the other, but rather to ensure the promotion of the rule of law, which entails that a court or tribunal cannot grant assistance to a party that has engaged in a corrupt act".

85 See Lord Mansfield's well-known dictum in Holman v Johnson [1775] 1 Cowp 341, 343: “The principle of public policy is this; ex dolo malo non oritur actio. No court will lend its aid to a man who founds his cause of action upon an immoral or an illegal act."

86 Strauss (n 8) 236.
} 
In contracts, the main test which English courts used to determine when a claimant's cause of action was "founded on illegality" was the test of reliance. According to the reliance test, which was based on the eighteenth-century authority in Holman $v$ Johnson ${ }^{87}$ and was affirmed by the House of Lords at the end of the twentieth century in Tinsley $v$ Milligan ${ }^{88}$ the illegality defence will prevent a claimant from recovering if the claimant needs to plead or lead evidence of illegality in order to establish her claim in the first place. ${ }^{89}$

In tort, where the test of reliance was not always able to capture the illegal situation, English courts had to develop different tests. For example, the Court of Appeal introduced in Cross $v$ Kirkby the inextricable test, whereby if a "claimant's claim is so closely or inextricably bound up with his own criminal or illegal conduct ... the court could not permit him to recover without appearing to condone the conduct".${ }^{90}$ After the House of Lords decision in Gray $v$ Thames Trains, ${ }^{91}$ two versions of the illegality defence in tort have been articulated ${ }^{92}$ : under the narrow version a claimant cannot recover any damage which is the consequence of a sentence imposed upon the claimant for a criminal or unlawful act, while under the wide version the claimant cannot recover for any damage which is the consequence of the claimant's own criminal or unlawful act whether or not convicted of a criminal offence.

While the tests employed by English courts to determine the illegality rule varied, depending on the type of claim, the scope of judicial function remained consistent with the evolution of the public policy doctrine as a set of rules whose application was mandatory irrespective of broader considerations of fairness. Indeed, while the rule on illegality was criticised as inflexible and often unjust, ${ }^{93}$ it left no room for English judges to exercise any sort of discretion by taking account of the perceived injustices of each case. Any attempt in the course of the twentieth century to rationalise the rule and transform it into a mere power was firmly rejected by the House of Lords originally and subsequently by the Supreme Court in 2016.

The most notable of these attempts was made by a number of first instance and Court of Appeal decisions in the 1980s and 1990s. For example, the decision in Euro-Diam Ltd v Bathurst introduced the "public conscience" test whereby the

\footnotetext{
87 Holman v Johnson (n 85) 341, 343.

88 Tinsley $v$ Milligan [1994] 1 AC 340 (HL).

${ }^{89}$ See Strauss (n 7) 243.

${ }_{90}$ Cross v Kirkby [2000] EWCA Civ 426 (per Beldam LJ).

${ }^{91}$ Gray $v$ Thames Trains [2009] UKHL 33.

92 Rachael Mulheron, Principles of Tort Law (CUP 2016) ch 10.

${ }^{93}$ See Shand (n 6) 165.
} 
illegality defence would apply when, "in all the circumstances it would be an affront to the public conscience" to allow the claimant to recover. ${ }^{94}$ Thus, under the public conscience test, a decision on the illegality defence was essentially a value judgement which would be taken on the basis of a range of circumstances surrounding the claim, including the significance of the illegality and the injustice of barring the claimant's claim due to such illegality. ${ }^{95}$

The Court of Appeal took the same approach in Tinsley $v$ Milligan, where the claimant and the defendant bought a house with jointly owned funds but registered it in the sole name of the claimant so that the defendant could fraudulently claim social security benefits. After the defendant repented and confessed to the benefit fraud, the two parties quarrelled and the claimant claimed ownership and possession of the whole house. The defendant filed a counterclaim for a declaration of co-ownership of the house, on the basis that the property was held by the claimant on trust for the parties in equal shares. The claimant invoked the illegality defence, arguing that the defendant could not rely on an arrangement which had an unlawful purpose.

Holding that it would be an affront to the public conscience not to grant the defendant her counterclaim, Nicholls LJ took a discretionary approach to illegality on the basis of a balancing exercise. Specifically, he held that in deciding whether to accept the illegality defence put forward by the claimant, the court had to "weight or balance" the "powerful case" for not aiding the defendant who had enjoyed fraudulent benefit claims against depriving her of her property in favour of the equally fraudulent claimant, and the fact that the defendant had repented of the frauds and had informed the Department of Social Security of the fraud. ${ }^{96}$ As Nicholls LJ noted, "the ultimate decision [in this case] calls for a value judgment".${ }^{97}$

However, while it rejected the claimant's illegality defence under the reliance test on the grounds that the defendant was able to successfully claim her title to the property because she relied on her contribution to the purchase of the property rather than on the fraudulent agreement, the House of Lords unanimously rejected the public conscience test. As the House of Lords confirmed, the public policy rule on illegality is not a principle of justice, but a principle of policy, whose application has to be indiscriminate. ${ }^{98}$ Rejecting the public conscience test, Lord Goff noted that its adoption "would constitute a

\footnotetext{
94 Euro-Diam Ltd v Bathurst [1990] 1 QB 1, 35.

95 ibid.

${ }^{96}$ Tinsley v Milligan (n 88) 319H; [1992] 2 All ER 391, 397-98. See also Strauss (n 7) 240

${ }^{97}$ Tinsley $v$ Milligan (n 88) 319.

${ }^{98}$ Holman $v$ Johnson (n 85) 355 (Lord Goff).
} 
revolution in this branch of the law, under which what is in effect a discretion would become vested in the court to deal with the matter by the process of a balancing operation, in place of a system of rules". .99

Two decades later, the Court of Appeal in Les Laboratoires Servier v Apotex 100 made another attempt to transform the ex turpi causa rule into a discretionary principle, by introducing a proportionality test. It is worth noting that in the meantime, the Law Commission had issued two Consultation Papers ${ }^{101}$ and one Report ${ }^{102}$ on the illegality defence, strongly arguing against the operation of the illegality defence as a rule of law. Instead, the Law Commission recommended that the illegality defence be allowed where its application could be firmly justified by one or more justifying policies, such as deterrence or the policy of maintaining the integrity of the legal system or the policy that the claimant should not profit from her own wrong.

Broadly drawing on the Law Commission's recommendations, Etherton LJ who gave the judgment at the Court of Appeal in Apotex stated that in deciding the illegality defence a court had to "take into account a wide range of considerations in order to ensure that the defence only applies where it is a just and proportionate response to the illegality involved in the light of the policy considerations underlying it". 103

However, on appeal, the Supreme Court in Apotex rejected Etherton's proportionality approach to the illegality defence. While the Supreme Court had held in Hounga $v$ Allen ${ }^{104}$ (just a few months before its decision in Apotex) that the harsh consequences of the illegality defence may sometimes be avoided by applying "another more important public policy", ${ }^{105}$ Lord Sumption, who gave the leading speech in Apotex, ${ }^{106}$ rejected any suggestion that the ex turpi causa rule can be a flexible principle allowing for considerations of justice. Lord Sumption observed that the Law Commission's recommendations were directly inconsistent with previous binding authority and made "the law

\footnotetext{
99 ibid 363.

100 Les Laboratoires Servier v Apotex (n 76).

${ }^{101}$ Consultation Paper No 160, "The Illegality Defence in Tort" (2001) and Consultation Paper No 189, "The Illegality Defence: A Consultative Report" (2009).

102 Law Commission Report No 320, "The Illegality Defence" (2010).

${ }^{103}$ Les Laboratoires Servier $v$ Apotex (n 76) 99. For this statement, he also relied on Lord Hoffmann's statement in Gray [2009] AC 1339 that "The maxim ex turpi causa expresses not so much a principle as a policy [which] is not based upon a single justification but on a group of reasons, which vary in different situations."

${ }^{104}$ Hounga v Allen [2014] UKSC 47; [2014] 1 WLR 2889 (SC).

105 See also Strauss (n 7) 262.

106 With whom Lord Neuberger, Lord Clarke and Lord Mance agreed but Lord Toulson disagreed.
} 
uncertain by inviting the courts to depart from existing rules of law in circumstances where it is difficult for them to acknowledge openly what they are doing or to substitute a coherent alternative structure". ${ }^{107}$ Lord Sumption noted that what matters for the purpose of the illegality defence is whether a turpitude existed and what the relationship between the turpitude and the claim is, not how badly the parties behaved in the case before the courts. Criticising the Court of Appeal's decision, he went on to state that although "the doctrine necessarily operates harshly in some cases", it is a legal rule which is rooted in public policy, not a mere discretionary power to be determined on the basis of the perceived balance of merits between the parties in a particular dispute. ${ }^{108}$

Despite the unequivocal confirmation of the illegality rule in Apotex, four years later, in July 2016, the Supreme Court (in plenary session) issued its decision in Patel v Mirza which marks a clear, if controversial, departure from longstanding authority stretching 200 years back to Holman $v$ Johnson. It is worth looking more closely into the Mirza case not only because it is the most recent Supreme Court decision on the illegality defence, but because it is a ruling with potentially significant implications for the doctrine of public policy in English law more generally.

\section{ii. Patel v Mirza}

The factual circumstances of the case are relatively straightforward. Patel transferred sums of money to Mirza to bet on the price of Royal Bank of Scotland (RBS) shares using advance insider information which Mirza anticipated obtaining from RBS contacts. Mirza's expectation did not materialise and eventually the betting did not take place. When Patel brought a claim against Mirza to recover the sums he had originally paid to him, Mirza relied on the illegality defence contending that allowing Patel to recover from a contract which was concluded by an illegal act, namely conspiracy to commit insider dealing, would be against English public policy.

The Court of Appeal held that under the reliance test, Mirza's defence did not succeed because the illegal scheme was not eventually executed. At the Supreme Court, all justices agreed with the Court of Appeal that Patel should be able to recover the money paid to Mirza under the illegal but unexecuted contract. However, the nine justices were divided in their reasoning, notably on whether the illegality defence should function as a legal rule or a flexible set of policies.

\footnotetext{
${ }^{107}$ Les Laboratoires Servier v Apotex (n 76) 444.

108 ibid 440.
} 
The leading judgment for the majority decision was given by Lord Toulson, with whom Lady Hale, Lord Kerr, Lord Wilson, Lord Hodge and Lord Neuberger agreed, although the President of the Supreme Court appeared to be sceptical about some of the reasons offered by Lord Toulson. Lord Mance, Lord Clare and Lord Sumption dissented on very similar grounds. The majority decision in Mirza rejected the reliance test in Tinsley and substituted it with a broader inquiry as to whether enforcement of a claim would be harmful to the public interest. According to Lord Toulson this inquiry was to be decided by considering a range of factors, including, first, the underlying purpose of the prohibition which has been transgressed and whether that purpose will be enhanced by denial of the claim; second, any other relevant public policy on which the denial of the claim may have an impact; and third, whether denial of the claim would be a proportionate response to the illegality, bearing in mind that punishment is a matter for the criminal courts. ${ }^{109}$

The reasoning of the SC majority decision to substitute the rule of illegality with a range-of-policy factors was based on the well-known criticism against ex turpi causa. Specifically, Lord Toulson described the effects that the rule of illegality has on the parties' contractual rights as "very unclear", 110 and noted that the test of reliance has led to problems of arbitrariness, uncertainty and potential injustice. ${ }^{111}$

It is hard to disagree with Lord Toulson's assessment of the reliance test. Its application has often been problematic in that it is effectively an artificial procedural test which allowed claimants to frame their claims creatively to avoid reliance on the underlying illegality. However, whether a radical shift from a rule-based to a range-of-factors approach was the right response to the problems associated with the application of the reliance test is questionable.

Indeed, it is submitted that Mirza's fundamental change in judicial attitude to public policy and illegality is unlikely to result in the required analytical coherence and legal certainty in this important area of English law. More importantly for the purposes of this article, it is further submitted that the Mirza ruling represents an unnecessary, and indeed unwarranted, departure from generally accepted principles on the doctrine of public policy and associated judicial function under English law, for the following reasons.

109 Patel v Mirza (n 8) 505.

110 ibid 476.

111 ibid 480. 
In the first place, the public policy inquiry introduced in Mirza is based on an open-ended list of factors which will lead to potentially considerable legal uncertainty. Lord Toulson's suggested list of factors and proportionality tests open up the inquiry to a wide range of public policies and considerations which in the views of a judge may be relevant to deny the enforcement of the claim. For example, the Law Commission's Report (2010) ${ }^{112}$ and Professor Burrows' Restatement of the English Law of Unjust Enrichment, 113 on whose work Lord Toulson relied heavily in his decision, identify a long list of policies and considerations which may become relevant to a public policy inquiry, including consistency; the need to prevent the claimant from profiting from his or her own wrong; deterrence; maintaining the integrity of the legal system; punishment; the degree of illegality of the conduct; whether the party seeking enforcement knew of, or intended, the conduct; how central to the contract or its performance the conduct was; how serious a sanction the denial of enforcement is for the party seeking enforcement.

Lord Toulson arrestingly admitted that it was not possible to lay down a prescriptive or definitive list of relevant factors "because of the infinite possible variety of cases". ${ }^{114}$ While inflexibility might have occasionally led to harsh outcomes under the rule-based approach, such an open-ended inquiry is likely to result in inconsistent and possibly contested policy justifications of public policy decisions in the future. Importantly too, it is against the typical approach of English courts which, as shown in the first part of this article, have taken a largely restrictive approach to public policy inquiries in the last century.

In the second place, the nature of the suggested factors set out by Lord Toulson, the Law Commission's Report and Professor Burrows invites courts to engage in moral and highly subjective evaluations. As Lord Sumption observed, the proportionality factor entails the risk that each judge will have to decide how illegal the illegality was or how much illegality matters. ${ }^{115}$ Crucially, the majority opinion in Mirza offers no standards or tests to guide judicial attitude in deciding questions on public policy. Thus, under the range-of-factors approach, the inquiry as to whether English courts should enforce an illegal or immoral contract is akin to a discretion, and judicial function is turned to a value judgement which Lord Mance warned might be conducted in "a highly unspecific non-legal sense". ${ }^{116}$

\footnotetext{
${ }^{112}$ Law Commission Report No 320, “The Illegality Defence" (n 102), para 2.55 et seq. 113 Andrew Burrows, Restatement of the English Law of Unjust Enrichment (OUP 2016).

114 Patel v Mirza (n 8) 501.

115 ibid 545.

116 ibid 526; cf Lord Neuberger at 517.
} 
However, inviting judges to exercise their discretion and make a value judgement without any guiding test or standard runs contrary to the way English judges typically exercise judicial function. As was shown in the first part of this article, under the modern doctrine of public policy, English judges could refuse enforcement of a claim as being against public policy only if the claim violated policies which were already crystallised into statutory or common law rules. An English judge had no discretion to introduce a new rule of public policy on the basis of what the judge believed would benefit the public interest. Exercising their discretion to decide whether a claim will be denied on the basis of whether the denial of the claim would be a proportionate response to the illegality and whether another policy, unspecified in advance, may be impacted, English judges will effectively introduce a new rule on public policy each time.

As was explained in the first part of this article, in applying public policy English judges have some degree of discretion in circumstances when, first, a dispute gives rise to a novel issue, and second, the application of a public policy rule is predicated on a more flexible test, such as the test of reasonableness in a dispute relating to restraint of trade. However, even in those circumstances judges are not permitted to engage in broad discussions about the public interest or about considerations of morality and justice. Under the doctrine of public policy as this evolved in the last century, judges are not free to arrive at new policies and new public policy justifications to support their decision. Even in deciding a novel situation, judicial discretion is constrained or at least guided by existing tests and principles of public policy. Crucially, the ex turpi causa rule is not a novel situation. It is a well-known legal question which has been addressed for centuries by a crystallised rule of law. By substituting the rule on illegality with a range of factors, the Mirza ruling effectively turns all cases on illegality into "hard" cases whose outcome will depend on value judgements including considerations of justice. As was demonstrated in the first part of this article, morality and justice were traditionally neither enshrined in the public policy doctrine itself nor used as a general test for its application.

In the third place, the range-of-factors approach introduces a discretionary and highly subjective approach to decision making which may eventually place the fundamental public policy behind the rule of illegality in jeopardy (well settled in English law since Holman $v$ Johnson), namely that it would be inappropriate for the system of justice to appear to assist in the enforcement of an illegal or immoral contract. ${ }^{117}$

117 Holman v Johnson (n 85) at 343. 
The straightforward, if inflexible, nature of the central public policy behind the illegality rule made the rule powerful and commanding. Whether the dismissal of the claim, arising out of an illegal or immoral contract, might confer an advantage on the defendant, who may also be implicated in the underlying illegality, was an unappealing prospect but eventually an acceptable implication of the implementation of the rule. ${ }^{118}$

Admittedly, the circumstances of different cases had occasionally affected the application of the rule on illegality and had given rise to inconsistent outcomes. ${ }^{119}$ For example, in Holman, Lord Mansfield held that the plaintiff's knowledge of the immoral cause of the contract did not affect the plaintiff's ability to recover from it, since he was not himself involved in the immorality. By contrast, in Pearce $v$ Brooks, ${ }^{120}$ a claim against a prostitute to recover money from the hire was held to be unenforceable on the basis that the plaintiff had knowledge of the illegality of the transaction. While Lord Denning later attempted to reconcile the two cases in JM Allan (Merchandising) Ltd $v$ Cloke, ${ }^{121}$ by introducing a distinction to the effect that "active participation debars, but knowledge by itself does not", his approach was theoretically rational but effectively artificial and eventually difficult to apply with consistency in practice.

However, these kinds of problems with the application of the rule, which occasionally led to the defeat of the underlying public policy, were seen as an unwelcome aberration of the rule-based approach. By contrast, under the range-of-factors approach, defeat of the central public policy against the enforcement of illegal and corrupt agreements comes as an acceptable outcome, if a judge decides that other policies, which are introduced as part of the balancing exercise, should prevail over the public policy against illegality.

Indeed, under the new approach the focus of the public policy inquiry is not on whether a contract is tainted by illegality; rather, it is on whether the claimant should recover or not on the basis of broader considerations reflected in a number of policies, including considerations of justice. ${ }^{122}$ This approach raises

\footnotetext{
118 As Lord Mansfield had characteristically observed in Holman v Johnson (n 85), "if the plaintiff and defendant were to change sides, and the defendant was to bring his action against the plaintiff, the latter would then have the advantage of it; for where both are equally in fault, potior est conditio defendentis".

$119 \mathrm{cf}$ James Goudkap, "The end of an Era? Illegality in Private Law in the Supreme Court" (2017) 133 LQR 14.

120 Pearce v Brooks (1866) LR 1 Ex 213.

${ }^{121}$ JM Allan (Merchandising) Ltd v Cloke [1963] 2 QB 340, 348.

122 Patel v Mirza (n 8) 109.
} 
two issues. First, it is again contrary to the way English judges exercised their judicial function in public policy inquiries. As the first part of this article has shown, while moral considerations were used by common law as an underlying justification of public policy rule, morality and justice were neither enshrined in the public policy inquiry itself nor used as a general test for the application of a public policy rule. Second, and possibly more significantly, by making the question of illegality only one factor of a broader value judgement and, importantly, by shifting the focus of analysis from illegality to recovery, the proposed range-of-factors test analytically disconnects the inquiry about whether a claim rooted in illegality should be enforced from the public policy against bribery and corruption. ${ }^{123}$

It has been observed that the historical context within which the public policy behind illegality was originally formulated has changed as regulation has been rapidly expanded in the last few decades. ${ }^{124}$ As a result, it is argued, the underlying policy in Holman is too extreme and inflexible to represent a sound legal policy in today's society. ${ }^{125}$ But while regulation to address bribery and corruption indeed intensified at an international level in the course of the twentieth century, corruption is still pervasive worldwide. ${ }^{126}$ Notably, England recently hosted an anti-corruption summit in London, with the then Prime Minister signalling the government's intention to intensify the battle against corruption in the United Kingdom and overseas. ${ }^{127}$ To that effect, the UK introduced new measures in the Bribery Act 2010 and the Criminal Finance Bill 2016 with the aim, inter alia, of depriving the corrupt of obtaining the benefit of their crimes.

It is thus questionable whether contextualising the public policy inquiry and introducing only a "proportionate" response to illegal or corrupt contracts are either appropriate or indeed desirable.

In any case, in the absence of statutory power, English courts lack the power to heavily qualify the public policy against illegality by introducing a new approach to judicial function which invites judges to mediate between a number of competing interests and policies implicated in the inquiry about

\footnotetext{
${ }^{123} \mathrm{cf}$ Lord Sumption ibid 544.

124 e.g. McHugh J in the Australian case Nelson v Nelson (1995) 184 CLR 538, 609. $125 \mathrm{ibid}$.

126 See Corruption Perceptions INDEX 2017 available at < https://www.transparency.org/news/feature/corruption_perceptions_index_2017 $>$ (last accessed 29 August 2018).

${ }^{127}$ See discussion in the Independent, available at < http://www.independent.co.uk/news/ world/politics/anti-corruption-summit-2016-nations-agree-to-increase-transparency-andcrackdown-on-money-laundering-a7026976.html> (last accessed 29 August 2018).
} 
illegality. ${ }^{128}$ While since the middle of the previous century the House of Lords and now the Supreme Court have been free to overrule their previous decisions and have shown greater readiness to adapt the common law to new conditions, ${ }^{129}$ the radical departure from consistent authorities of centuries past is at odds with the typically incremental manner in which common law develops. ${ }^{130}$ That being so, the ruling of the Supreme Court in Mirza borders on legislative function. ${ }^{131}$

After observing that the ex turpi causa rule could only be modified by statute, unless public policy views of commercial morality had clearly come in a particular age to doubt that honesty is the best policy, Lord Sumner in Rodriguez v Speyer ${ }^{132}$ went on to note:

If the application of a rule founded on public policy admits of doubt, it is legitimate to consider that policy, in order to decide whether the case falls within the public mischief, which the rule purports to prevent, but when the rule and its application are perfectly clear and admit of no doubt the mischief must be assumed, and the policy needs no inquiry. ${ }^{133}$

There have been no indications that the public policy behind the rule of illegality "admits of doubt", nor did the majority decision in Mirza suggest so. The Law Commission's work, upon which Lord Toulson's lead decision in Mirza heavily relied, did not suggest that the application of the reliance test resulted in unsatisfactory outcomes, which were largely considered to be unfair. ${ }^{134}$ Rather the Law Commission was critical of the way decisions on illegality were reached, being occasionally arbitrary, non-transparent and potentially only unjust. ${ }^{135}$ For all its inflexibility, the rule of illegality had mostly worked well and had led courts to arrive at outcomes which were generally acceptable. In Tinsley, for example, the respondent was not eventually deprived of her right in the property, as the court held that illegality of a transaction does not render equitable rights void. Equally, in Mirza, the dissenting justices who remained faithful to the rule found that the claimant

\footnotetext{
${ }^{128}$ cf Mance (n 73) at 188.

129 Bell (n 4) at 3.

$130 \mathrm{cf}$ Lord Mance (n 73) at 527 and Lord Sumption at 531.

${ }^{131}$ Lord Mance referred to it as "tearing up the existing law and starting again", at 526. cf also Lord Clarke at 529.

132 Rodriguez v Speyer (n 15).

133 ibid 126.

${ }^{134}$ Law Commission Consultative Report (n 102) para 3.50 et seq; Lord Toulson also accepted that in Patel v Mirza (n 8) at 477.

${ }^{135}$ Law Commission Consultative Report, ibid.
} 
should be able to recover the money paid to the respondent. ${ }^{136}$ It is questionable, therefore, whether the fundamental change in the illegality inquiry, which the Mirza ruling introduced, was necessary at all.

Reforming the existing public policy rule of illegality to allow for more flexibility and to prevent harsh outcomes might have been a sounder course of action for the Supreme Court. There is clear merit, for example, in the suggestion of Lord Mance and Lord Sumption to accord broader scope to the principles of rescission and restitution, which in the context of the illegality defence have become particularly restricted by twentieth-century authority. ${ }^{137}$ A more effective use of these principles would allow English courts to restore the parties to the position they would have been in, had they never entered into the illegal contract. ${ }^{138}$ Importantly, it would have also allowed English courts to find that both the claimant and the respondent are in certain circumstances prevented from profiting from their own illegality, which was a major consideration of Lord Toulson's leading judgment. There is also merit in the views of Lord Mance and Lord Clarke that the power of the court to deny recovery on the ground of illegality should be limited to well-defined circumstances to compensate for its draconian nature. ${ }^{139}$ Developing the public policy rule on illegality, rather than abolishing it, would have been more consistent with the common law tradition of incremental evolution.

While it is too soon to tell how the public policy inquiry on ex turpi causa will develop, from the very limited number of cases that have been discussed since the Supreme Court ruling in Mirza, it is clear that judicial function has already started to change in relation to illegality. Judges, as the leading decision in Mirza invited them to do, seemingly feel empowered to make broader evaluations about what is unfair, disproportionate and contrary to the public interest in deciding a question of public policy.

For example, in Singularis Holdings Ltd v Daiwa Capital Markets Europe Ltd, ${ }^{140}$ a company brought an action for the recovery of sums held to its benefit in a client account by the defendant stockbroker. The defendant relied on the illegality defence on the basis that payments to his account were fraudulently

\footnotetext{
136 Patel v Mirza (n 8). Lord Mance (at 522 et seq) and Lord Sumption (at 538 et seq) reconciled the rule of illegality with rules of rescission, such as the principle of locus poenitentiae, which reinstates the parties to the position that they would have been in, had illegality not occurred. 137 Patel v Mirza (n 8). See Lord Mance at 523 and Lord Sumption at 538 et seq and Wootwich Equitable Building Society v Inland Revenue Comrs [1993] AC 70, 172 and more recently Deutsche Morgan Grenfell Group plc v Inland Revenue Comrs [2007] 1 AC 558.

138 Patel v Mirza (n 8), a proposal which Lord Neuberger described as an existing legal rule.

139 Patel v Mirza (n 8), Lord Mance at 521 and Lord Clarke at 528.

140 Singularis Holdings Ltd v Daiwa Capital Markets Europe Ltd [2017] EWHC 257 (Ch).
} 
made by the company's director. Allowing recovery of the payments, the judge reasoned, without any explanation or justification, that it "would not be contrary to the public interest to allow [the company] to enforce its claim, nor would it be harmful to the integrity of the legal system for this claim to succeed". 141

In John McHugh $v$ Ophelia Okai-Koi, ${ }^{142}$ the defendant in criminal proceedings was acquitted of causing death by dangerous driving, but convicted of causing the death of the wife of the claimant by careless driving while the wife of the claimant was on her car bonnet. When the claimant husband sought damages in civil proceedings, the defendant relied on the defence of ex turpi causa on the grounds that the claimant and his wife, who were highly intoxicated, had verbally and physically attacked the defendant at the time of the accident. Relying on the Mirza ruling, the judge engaged in a range of subjective evaluations such as whether the public interest would be harmed by the denial of the claim for damages in circumstances where the defendant had been convicted by a jury of causing death by careless driving; ${ }^{143}$ whether to take account of the public policy consideration that the denial of the claim would deprive the claimant's children of damages, as dependants, in circumstances for which they were not responsible; ${ }^{144}$ and whether the denial of the claim would be proportionate in circumstances where the defendant had been convicted of causing death by careless driving. ${ }^{145}$

It is evident that these kinds of considerations, which the Mirza ruling introduced into the public policy inquiry, blur the distinction between legal reasoning and value judgements and allow judges discretion to decide important questions of public policy on the basis of subjective opinions. While the new approach to public policy and illegality may allow more flexibility, it is unlikely that it will achieve less arbitrary outcomes and more analytical coherence, the absence of which featured largely in criticism of the illegality rule. ${ }^{146}$

More importantly for the purposes of this article, the Supreme Court decision in Mirza invites judges to engage in an open-ended and highly subjective inquiry which is contrary to fundamental considerations underpinning the

\footnotetext{
141 ibid para 100.

142 John McHugh v Ophelia Okai-Koi [2017] EWHC 1346 (QB).

143 ibid 19.

144 ibid 21.

145 ibid 22.

${ }^{146}$ Law Commission, Consultative Report (n 102) para 3.50 et seq.
} 
modern doctrine of public policy and associated judicial function, as was demonstrated in the first part of this article.

\section{Conclusion}

In conclusion, it is worth summarising the main findings and suggestions of the preceding analysis. In the first place, it was shown that since the beginning of the twentieth century, the concept of public policy in English law evolved as a structured doctrine of exceptional character and restrictive scope. More importantly, for the purposes of this article, it was demonstrated that the modern doctrine of public policy would not allow judges, first, to take judicial notice of public policy circumstances which lie outside the law, notably considerations of justice, and, second, to disregard a legal rule of public policy because the judge disapproved of the policies underlying that rule. As was explained, under the modern concept of public policy, it would not be appropriate for an English judge to introduce a new rule of public policy on the basis of what the judge believed would be the most appropriate policies to pursue for the benefit of the public.

Further, it was demonstrated that, in deciding questions of public policy, English judges have generally no or very limited discretion, except in two circumstances, namely, when they address a novel situation and when applying rules that are predicated on flexible tests which allow them to mediate considerations of public policy through more open questions such as what is reasonable or not. As was noted, this restrictive approach to judicial function is consistent with the general approach of English law which largely opposes discretion and value judgements, particularly in the area of contract law.

In the light of the above findings, it was suggested that the SC's ruling in Mirza contravenes a number of traditionally accepted propositions on the appropriate judicial function in relation to questions of public policy. Specifically, it was suggested that the range-of-factors approach invites English judges to engage in open-ended and highly subjective evaluations without the benefit of a guiding test or standard. This approach is effectively akin to unfettered discretion and turns all questions relating to illegality into hard cases, allowing English judges to introduce new rules on public policy in "a highly unspecific non-legal sense."

Finally, it was suggested, that the discretionary and highly subjective approach to decision making introduced by Mirza might eventually place the fundamental public policy against illegality in jeopardy. It was submitted that, by contextualising the inquiry about illegality, the range-of-factors test 
analytically disconnects the inquiry about whether a claim rooted in illegality should be enforced from the public policy against bribery and corruption. 